\title{
How Total Quality Management Mediates Antecedent Variables of Employee Performance?
}

\author{
Alwan Sri KUSTONO ${ }^{1}$ \\ Received: August 01, 2020 Revised: October 11, 2020 Accepted: November 05, 2020
}

\begin{abstract}
The research objective was to find out how Total Quality Management (TQM) mediates antecedents of employee performance variables? The research was conducted with a quantitative approach while the research design was cross sectional. The research model was tested using the structural equation modeling approach with partial least square analysis tools to test the influence among research variables. The research sample consisted of 315 respondents who answered a questionnaire in August-September 2019 at manufacturing companies in East Java. The results showed that situational leadership did not affect employee performance, but did affect the successful implementation of TQM. The performance measurement system has no direct effect on employee performance. The performance measurement system has a direct effect on employee performance. Organizational culture has a direct effect on both employee performance and the application of TQM, so that the application of TQM can improve employee performance. TQM implementation variable acts as a mediation between situational leadership and organizational culture on employee performance. The relationship that was originally a direct influence turned into an indirect effect through TQM. The TQM variable is not proven to be an intervening variable between the performance measurement system and employee performance. There is a direct relationship between these two variables.
\end{abstract}

Keywords: Total Quality Management, Employee Performance, Advanced Manufacturing Industry, Performance Measurement Systems, Organizational Culture

JEL Classification Code: L60, D23, M41

\section{Introduction}

The achievement of company goals cannot be separated from its employees' quality level. Competent employees are employees who can complete tasks and take up responsibilities effectively. Good employee performance provides a company with the opportunity to react and anticipate market changes quickly and flexibly. In tough competition, the company must always try to improve the quality of its products. Adding value is very important to cause consumer loyalty. Companies that have consumers

${ }^{1}$ First Author and Corresponding Author. Faculty of Economics and Business, University of Jember, Indonesia [Postal Address: Kampus Tegalboto, Jl. Kalimantan No.37, Krajan Timur, Sumbersari, Kec. Sumbersari, Kabupaten Jember, Jawa Timur 68121, Indonesia] Email: alwan.s@unej.ac.id

(c) Copyright: The Author(s)

This is an Open Access article distributed under the terms of the Creative Commons Attribution Non-Commercial License (https://creativecommons.org/licenses/by-nc/4.0/) which permits unrestricted non-commercial use, distribution, and reproduction in any medium, provided the original work is properly cited. who are satisfied with the value of the product produced are expected to be going concerned.

The addition of value can be obtained if the performance of employees meets expectations. Employee performance is the work of employees in fulfilling obligations in accordance with their duties and responsibilities. Performance shows the level of achievement of the implementation of activity in realizing the company's goals, objectives, vision, and mission. An understanding of the factors that affect employee performance is very important. Previous research shows that employee performance is influenced by leadership style, performance measurement systems, and culture. Some studies conclude that leadership style, performance measurement systems, and culture influence employee performance. Several other studies have shown that these variables do not affect employee performance.

Employee evaluation systems must enable employees to optimize their potential. Performance improvement is achieved on an ongoing basis. Employees are aware to always improve their performance because they have clear goals based on reasonable abilities. The evaluation 
process is carried out to measure the level of work results of employees in accordance with established standards. The results of the evaluation are discussed to find a solution in case of irregularities. It can be said that evaluation is an act of measuring employee contributions to company goals. The contribution is in the form of achieving the company's goals that have been set to be achieved. An employee performance appraisal system is a measure of employee achievement performance. The information generated is useful for strategic decision-making and company policy.

The company is a collection of individuals who have different backgrounds and competencies. These differences can hamper the company's operation if it is not managed properly (Hulima, 2016; Seyedi et al., 2019; Wambugu, 2014). To be a strong business organization, a company must have a strong culture. Organizational culture governs the values and norms that direct individuals to achieve company goals. Employee behavior must be managed and controlled so that it remains positive and productive. Organizational culture is related to behavior in situations faced by the company. The company's culture indirectly shapes the way they interact, communicate, and react to internal and external relations (Nguyen et al., 2020). Organizational culture has various characteristics, depending on the various points of view used. Some organizational culture dimensions that are often revealed are the reach of authority, the tendency of individualism, risk-takers or avoiders, innovation-oriented or ability, authoritarian or participatory. Previous research revealed that employee performance is influenced by organizational culture (Hulima, 2016; Rad, 2006; Saad \& Abbas, 2018; Salehipour \& Ah mand, 2018; Seyedi et al., 2019). Fanani (2016) and Rotberg (2016) found different results. According to them, organizational culture is not a determining factor in employee performance (Fanani \& Jalil, 2016; Rotberg, 2016). Organizational culture is individual subjective values that are not related to the organization. The way employees communicate, interact, and solve problems is a personal culture.

Different studies regarding variables that are determinants of employee performance raise questions about the cause (Lukmana et al., 2013; Azizah et al., 2017; Dasrita et al., 2015; Dwi Hidayati, 2017; Fanani \& Jalil, 2016; Mawarni \& Yuliansyah, 2015; Rotberg, 2016; Syauta et al., 2012; Wanjiku \& Lumwagi, 2014). One possibility is the existence of variables that affect the relationship between employee performance variables with leadership, company environment, and corporate culture. One of the management information systems that are implemented is using enterprise resource planning (ERP). ERP is a software that gives companies the ability to manage human, financial, and non-financial resources to support the company's competitiveness. The information system is carried out with complete integration, and the outputs are in the form of comprehensive company information. ERP is a technology resource that contains comprehensive information, purchasing, production processes, marketing, support, and inventory management. The use of ERP equipped with hardware and software to coordinate and integrate information data in each area of business processes. Decision making can be done quickly because the analysis is carried out simultaneously from various company functions (Kustono \& Valencia, 2017).

In the advanced manufacturing industry, quality is an absolute criterion that must be met. Some of the techniques used are Kaizen Costing, Just in Time, Six Sixma, Activity Based Costing, and Total Quality Management (TQM). Concepts, paradigms, and techniques are used to achieve a certain level of quality (Basheer et al., 2016). TQM in the operational environment gets a lot of attention from practitioners, managers and researchers because of its significant contribution to business performance, costs, customer satisfaction, customer loyalty, and profitability (Talib et al., 2011). In the implementation of TQM, it is important for organizations to identify the main factors, which must be given special attention to ensure the successful implementation of TQM programs and strategies (Trang \& Do, 2020). Supporting industries have made a significant contribution to economic growth in Vietnam. Supporting industries focus on providing raw materials, spare parts and components for the manufacturing industry (Rahman \& Saima, 2018), thus becoming a substantial determinant of Vietnam's industrialization process. In order to increase the productivity and quality of Vietnam's supporting industries, TQM is an efficient tool in improving quality and business performance.

The successful implementation of TQM depends on the ability of human resources owned by the company. HR not only has competence, but also must have a positive mindset. The company focuses on meeting customer needs with effective production processes, good teamwork, and quality products. Optimizing the competence and resources of the company provides the company's competitiveness in the global market. The TQM system is carried out comprehensively so that both internal and external customers are satisfied, defective products are reduced drastically, reprocessing is zero, and complaints are decreased. TQM is commonly found in advanced manufacturing companies. The advanced manufacturing industry implements the integration of data processes for each function in company management in a transparent and high level of accountability. The concept of integration is known as the concept of Enterprise Resource Planning (ERP).

This research was conducted at an advanced manufacturing company characterized by ERP. The aim is to ascertain whether these companies have implemented TQM optimally and consistently (Koupaei \& Movahedi, 
2014; Saleh Al-Dhaafri et al., 2014). From the explanation above, the researcher is interested in examining the effect of the work environment, organizational culture, and situational leadership on employee performance in advanced manufacturing companies. Research is expected to reveal the role of applying TQM as an intervening variable on the relationship among these variables. The question is whether situational leadership, performance measurement systems, organizational culture, and TQM affect employee performance and whether TQM is a mediating variable relationship between these variables.

\section{Literature Review}

\subsection{Performance Measurement System}

Performance measurement is carried out to measure whether the activities carried out by employees, organizational units, or certain organizational functions are in accordance with the standards, achievement measures, or criteria set (Dasrita et al., 2015; Nilamsari, 2018). In implementing company operations, conditions and situations often change. This requires adjustments. Companies must have a system that guarantees that employee performance is measurable. Employees who have good performance gains are rewarded, and bad ones get punishment. Such a performance measurement system is a mechanism for creating a just work environment (Striteska \& Jelinkova, 2015; Wei \& Xiong, 2020).

Employees also benefit from a good performance measurement system. They obtain information on how their work is valued, value-added activities, and non-value-added activities. The better performance measurements used by the company leads to an increase in employee performance. The performance measurement system is carried out on an ongoing basis, with clarity of criteria having the benefit of feedback information (Nilamsari, 2018; Noronha et al., 2016). Contingency theory explains that the design of management information systems should provide the right information for the goals to be achieved by the company, both its actions and anticipations so that the company can live on.

In general, performance measurements include the objectives to be achieved, how to achieve them, and what resources are used to achieve them. The mechanism that is formed will connect the company's strategy with the actions taken. In the traditional performance accounting model, it generally focuses on financial measurement. This is considered insufficient when the measurement system ignores non-financial factors. Not including nonfinancial factors as elements in performance measurement causes improvements and innovations that are carried out unsustainably. The modern approach emphasizes the balance between financial and non-financial factors (Dahal, 2018). Previous studies have shown that a good performance measurement system affects employee performance (Dahal, 2018; Dasrita et al., 2015; Lau \& Oger, 2019). This influence is obtained because the performance measurement system provides positive motivation for employees always to improve their performance, help manage employees both concerning rewards and penalties, provide information about employee competencies and follow-up to increase competency. Based on the description above, the following hypotheses are formulated:

H1: The performance measurement system influences the performance of employees of advanced manufacturing companies.

H2: The performance measurement system influences the implementation of TQM in advanced manufacturing companies.

\subsection{Situational Leadership}

The manager becomes the leader of his team. He is responsible for directing and maintaining that the activities of the units, subdivisions, or sections they lead remain in harmony with the company's goals (Machimbi, 2017; UlHameed et al., 2019). Good leadership is leadership that cares for their subordinates. The attention is on the competence and individual factors. Leadership with these characteristics is known as situational leadership (Mustika, 2019; Yuliana, 2013; Zulaihah, 2017).

Leaders who carry out the situational leadership style perform two functions in a balanced manner, namely guiding and helping to solve technical problems and provide socioemotional support to subordinates in carrying out their duties and work. This requires the full attention of the leader to his subordinates. The manager must be able to see the competencies per each of his subordinates so that the tasks given are completed properly. This leadership style treats individuals according to the characteristics of subordinates. Employees who are considered technically qualified, then managers can reduce the orientation of the task and divert to the socio-emotional relationship. Important factors in evaluating the ability of subordinates to carry out work are knowledge of the task, skills in completing tasks, the ability to solve jobs and the ability to finish work on time.

The success of situational leadership is influenced by leaders' ability to see the potential possessed by their subordinates. Several types of leadership styles can be adapted to the characteristics of subordinates. If the subordinates' level of maturity is low, the leader can apply the instruction model - the leader commands, specifically, direct and strict supervision. In certain environments, when competence is relatively low or has a low motivation, leaders can use roles as 
directors and supporters. He must play a role in offering tasks to the capable. On the other hand, he acts to give direction to those who have a low ability (Hidayati, 2017).

Situational leadership is essentially leadership carried out with different styles according to the characteristics of subordinates. This suitability gives comforttohis subordinates. Subordinates feel the work environment is supportive so that they can work optimally. Previous research shows that the situational leadership style influences the success of TAM implementation. Appropriate management behaves in accordance with the conditions of subordinates, causing no gaps in carrying out tasks, jobs, and responsibilities. On a quality basis, the proper placement of subordinates certainly has an impact on job optimization. Quality orientation is achieved because managers pay attention to constraints and solutions related to the competencies of the people they lead.

Leadership in which there are aspects of the relationship between leaders and subordinates, assignments, authority, and authority influence employee performance (Hamidi, 2009; Ozdal \& Oyebamiji, 2018). An effective leadership style puts subordinates in situations where he can work optimally. Based on the description above, the following hypotheses are formulated:

H3: Situational leadership influences employee performance in advanced manufacturing companies.

H4: Situational leadership influences the application of $T Q M$ in advanced manufacturing companies.

\subsection{Organizational Culture}

The institutional theory explains that culture is the structure that shapes human behavior. Culture uses values, norms, standards of behavior, and interdependence among individuals involved in it. Organizational culture is composed of subjective things that are rooted in an organization and form characteristics that affect every individual in a related organization to achieve certain goals. Someone who is in an organization adapts to the culture of the organization. Individuals who are unable to adapt will be excluded or ostracized due to being alien, among others. Employee performance is an output of employee behavior, so it cannot be separated from cultural influences. Organizational culture functions to overcome the problems of internal integration by building models of personal relationships and tasks. The way employees can communicate, discuss, argue, or form a consensus is part of the culture that develops in the company. The company has certain characteristics that are different from other companies. It can be said that organizational culture is a set of recognized and agreed values and is a differentiator with other organizations.

Culture is a factor in leveraging employee performance (Maulina \& Natakusumah, 2020). If the employee is comfortable with the developing values, he will work hard to affect the quantity and quality of the output produced.
A conducive culture encourages employees to contribute to efforts to achieve the company's strategic goals. Previous research found that organizational culture significantly influences an organization (Aletaiby et al., 2017; L.Pathiranage, 2019; Sukdeo et al., 2017; Wisna, 2015). They concluded that culture is a value inherent in organizations. Individuals who are part of the organization directly follow the pattern of behavior that has been built. Its performance will be in line with how employees accept or reject company values. An organizational culture that grows in the work environment affects employee performance. Organizational culture is a collection of key values aggregation. If the employee views these values as good, he appreciates and follows those values, and the employee voluntarily performs their duties and obligations. Based on the theory and previous research, then the hypotheses can be formulated as follows:

\section{H5: Organizational culture influences employee perfor-} mance

H6: Organizational culture influences the implementation of TQM

\subsection{Total Quality Management}

Total quality management (TQM) is believed to be one of the primary sources on business development. Although TQM normally generates a sustainable competitive advantage, there is, surprisingly, little or no theory to confirm (Koupaei $\&$ Movahedi, 2014). The quality paradigm is for employees always to improve their skills and competencies. Companies that implement TQM make quality a key success factor to achieve company goals. Total Quality Management requires active management and employees to make continuous improvements.

TQM can never be separated from stakeholder involvement, increased employee competence, and top commitment. Stakeholders are parties with interest in the company (Bahbah, 2018; Machimbi, 2017). The application of TQM leads to the fulfillment of stakeholder satisfaction. Some of the company's activities are carried out with the involvement of these parties. In the internal scope, the customer is the recipient of the next process or activity. The orientation of the fulfillment of internal customer satisfaction results in the reduction of damaged goods, defective goods, or improvements that are non-value-added. The company must also make efforts to ensure that relations with suppliers are good. The process can be done with a long-term contract.

These three things cannot be separated from management support. Implementing TQM requires consistent support from top management. Continual improvement requires a flexible and dynamic organizational structure so that the reaction to environmental changes can be carried out quickly. TQM makes every employee carries out their activities with high-quality standards. Customer fulfillment characterizes 
increased employee performance needs with precision (Gul et al., 2012; Munizu, 2013; Sukdeo et al., 2017). Previous research found that TQM had a significant positive effect on employee performance. Quality improvements periodically improve employee performance. Based on the description above, the following hypothesis is formulated:

H7: Application of TQM influences the performance of advanced manufacturing company employees.

\section{Methodology}

This research is designed as a quantitative study, which is intended to test the hypotheses. The research design was a cross-sectional study. Data were collected from different sample units, performed once, and at different times. The population of this research is 10 manufacturing companies that have met the sampling criteria. The method used is the snowball method. The sampling criteria are as follows: (a) employees in manufacturing companies that implement ERP. Companies that implement ERP are companies that are developed and are considered to consistently run a total quality management system; (b) the sample employees are characterized by a minimum of two years of service. This is based on the consideration that with a service period of two years the employee's performance has been measured. The sample studied was 315 employees of manufacturing company in East Java using a questionnaire. The analysis tool used is the structural equation model (SEM) with the partial least square approach.

\section{Results and Discussion}

This descriptive analysis is used to describe the research variables descriptively by interpreting the results of the tabulated data to support the results of the research analysis so that it can be explained in more detail about the research findings. The results are shown in Table 2.

Table 2: Results of Statistical Descriptive Analysis

\begin{tabular}{|l|c|c|c|c|}
\hline Variable & Minimum & Maximum & Mean & $\begin{array}{c}\text { Std. } \\
\text { Dev }\end{array}$ \\
\hline $\begin{array}{l}\text { Situational } \\
\text { Leadership }\end{array}$ & 19 & 25 & 24,02 & 1,309 \\
\hline $\begin{array}{l}\text { Performance } \\
\text { Rating System }\end{array}$ & 28 & 40 & 38,67 & 2,046 \\
\hline $\begin{array}{l}\text { Organizational } \\
\text { Culture }\end{array}$ & 21 & 28 & 25,00 & 2,443 \\
\hline TQM & 40 & 55 & 51,92 & 2,636 \\
\hline $\begin{array}{l}\text { Employee } \\
\text { Performance }\end{array}$ & 34 & 40 & 38,92 & 1,524 \\
\hline
\end{tabular}

Based on the results of the descriptive analysis as presented in Table 2, for the assessment of situational leadership variables, the mean value is 24.02 with a value greater than the minimum value of 19 and a standard deviation of 1.309 , and this indicates that employees of advanced manufacturing companies in East Java tend to have good situational leadership. Likewise, the mean value of the performance appraisal system equal to 38.67 is greater than the minimum value of 28 , meaning that the employees of advanced manufacturing companies in East Java have a good performance appraisal system. The mean value of TQM is 51.92 greater than the minimum value of 40 , and the mean value of performance is 28.82 greater than the minimum value of 23 . The mean value of performance is 38.92 greater than the minimum value of 34 , which indicates that employees at advanced manufacturing companies in East Java tend to have TQM, and good performance.

\subsection{Hypothesis Test (t-test)}

Hypothesis testing one through four hypotheses is made with partial least squares technique with the Visualpls tool. The partial least square path analysis test results are performed by specifying the relationship between variables in the inner model.

The path coefficient test results for the inner model for the two-equation models are shown in table 3. The test aims to determine each exogenous variable's effect on endogenous variables at a certain level of significance. $\mathrm{P}$-values are significant values. If the P-value is below 0.05 , the hypothesis is accepted. Conversely, if above 0.05 , the hypothesis is rejected.

Based on Table 3, it is noted that:

1) The direct influence of situational leadership (X1) on TQM (Z1) of 0.314 in a positive direction.

2) The direct effect of Performance Measuring System (X2) on employee performance (Y) of 0.522 in a positive direction.

3) The direct effect of the performance measurement system (X2) on TQM (Z1) of 0.190 in a positive direction.

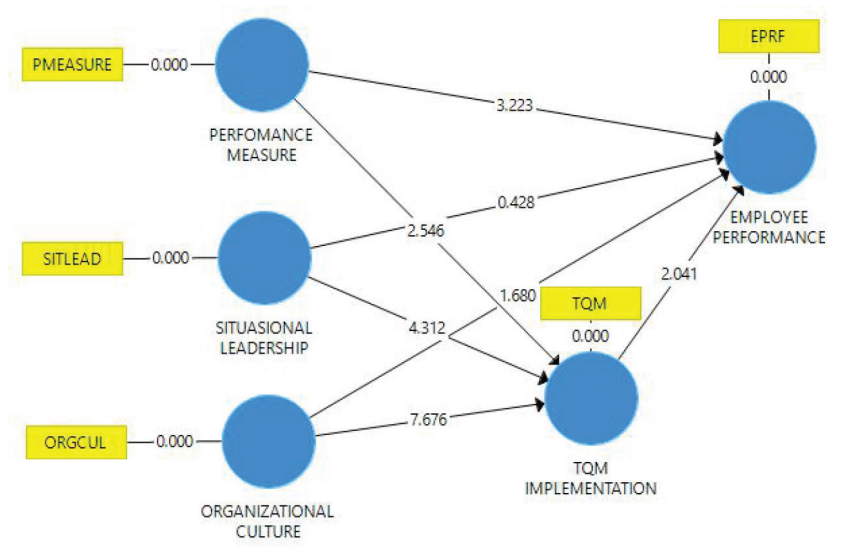

Figure 1: Result of Hypotheses Testing 
Table 3: Path Coefficients

\begin{tabular}{|l|c|c|c|c|c|}
\hline & $\begin{array}{c}\text { Original } \\
\text { Sample }\end{array}$ & $\begin{array}{c}\text { Sample } \\
\text { Mean }\end{array}$ & $\begin{array}{c}\text { Standard } \\
\text { Deviation }\end{array}$ & T Statistics & P Values \\
\hline Org. Culture $\rightarrow$ Employee Perf. & -0.360 & -0.309 & 0.214 & 1.680 & 0.094 \\
\hline Org. Culture $\rightarrow$ TQM & 0.547 & 0.537 & 0.071 & 7.676 & 0.000 \\
\hline Perf. Measurenment $\rightarrow$ Employee Perf. & 0.522 & 0.504 & 0.162 & 3.223 & 0.001 \\
\hline Perf. Measurenment $\rightarrow$ TQM & 0.190 & 0.195 & 0.075 & 2.546 & 0.011 \\
\hline Sit. Leadership $\rightarrow$ Employee Perf. & -0.085 & -0.038 & 0.198 & 0.428 & 0.669 \\
\hline Sit. Leadership $\rightarrow$ TQM & 0.314 & 0.319 & 0.073 & 4.312 & 0.000 \\
\hline TQM $\rightarrow$ Employee performance & 0.697 & 0.631 & 0.342 & 2.041 & 0.042 \\
\hline
\end{tabular}

Tabel 4: Indirect Effects

\begin{tabular}{|l|c|c|c|c|c|}
\hline & $\begin{array}{c}\text { Original } \\
\text { Sample }\end{array}$ & $\begin{array}{c}\text { Sample } \\
\text { Mean }\end{array}$ & $\begin{array}{c}\text { Standard } \\
\text { Deviation }\end{array}$ & T Statistics & P Values \\
\hline Sit. Leadership $\rightarrow$ TQM $\rightarrow$ Employee Perf. & 0.219 & 0.187 & 0.098 & 2.241 & 0.025 \\
\hline Org. Culture $\rightarrow$ TQM $\rightarrow$ Employee Perf. & 0.382 & 0.336 & 0.183 & 2.086 & 0.037 \\
\hline Perf. System $\rightarrow$ TQM $\rightarrow$ Employee Perf. & 0.133 & 0.138 & 0.105 & 1.263 & 0.207 \\
\hline
\end{tabular}

4) The direct effect of organizational culture (X3) on TQM (Z1) is 0.547 in a positive direction.

5) The direct effect of TQM (Z1) on Employee performance (Y) of 0.697 in a positive direction.

6) The relationship between other variables is not significant. Situational leadership (X1) and performance measurement system (X2) do not affect Employee Performance.

Based on these tests, it can be stated that the exogenous variable that has the greatest direct effect on employee performance (Y) is organizational culture. Situational leadership variables and the performance measurement system affect the implementation of TQM, but do not directly affect managerial performance.

Based on Table 4, it is known that:

1) The indirect effect of situational leadership (X1) on managerial performance through TQM $(Z)$ is 0.219 in a positive direction.

2) The indirect effect of organizational culture (X3) on employee performance (Y) through TQM (Z) of 0.382 in a positive direction.

Based on these tests, it can be stated that the performance measurement system (X2) has the greatest indirect effect on employee performance (Y) employees of advanced manufacturing companies in East Java. Based on the results of data analysis conducted and described above, it is known that the independent variables, namely, situational leadership, performance appraisal system, TQM, have a significant effect on the performance of employees of advanced manufacturing companies in East Java.

\subsection{Effect of Situational Leadership on Employee Performance}

Based on the path coefficient analysis, the influence of situational leadership on employee performance shows a significant $p=0.669$. Situational leadership does not affect the performance of employees of advanced manufacturing companies in East Java. Thus, the first hypothesis, which states that situational leadership influences the performance of employees of advanced manufacturing companies in East Java, is rejected. The influence of situational leadership on the performance of employees of advanced manufacturing companies in East Java indicates that situational leadership applied by the leaders of advanced manufacturing companies in East Java does not directly affect employee performance. The task distribution system, directing before carrying out the task, providing deadlines in carrying out the task, coordinating the work situation, and overseeing the task's implementation, is not able to improve the performance of employees of advanced manufacturing companies in East Java. Situational leadership is the process of forming and maintaining relationships between superiors and subordinates. This relationship must be mutually supportive of a leader and his subordinates. Leaders should offer concrete support, direction, and assistance when subordinates go through difficult periods. In general, subordinates obtain important tasks or fix problems that already exist. 
This study's results are in line with previous studies (Azizah et al., 2017; Ghani Al-Saffar \& Obeidat, 2020). Leadership does not affect employee performance. Leaders' behavior will be effective depending on the level of readiness of leaders in trying to influence others. This shows that high leadership does not always make employees willing to perform tasks. In addition to the leading factor, another possibility is that external conditions also influence employee performance. The results of this study are not in line with research conducted by Hamidi (2009), Ozdal and Oyebamiji, (2018) Mustika (2019), Yuliana (2013). The study found that situational leadership factors, including the subordinate supervisor variable, task structure, and power and authority, had a significant influence on employee work performance.

\subsection{Effect of Situational Leadership on the Application of TAM}

The results showed that situational leadership influences TQM at a significance level of 0.000 . The hypothesis that situational leadership influences the implementation of TAM is accepted. Managers who have leadership characteristics are better able to raise the level of TAM success. Situational leadership is needed to support the implementation of TQM because it is a management approach, not a narrow quality control technical approach. This is a strategy and management philosophy that tries to integrate all organizational functions that involve involving all lines of the company. The involvement aims to optimize the performance of employees of the company. Situational leadership characteristics are aligned with the needs of the successful implementation of Total Quality Management. Situational leadership demonstrates the ability of leaders to engage and empower subordinates - participation in joint decision-making. The alignment of this leadership style will support continuous improvement. Relationships with suppliers, customer involvement, training, top management commitment can be maintained. Top management's commitment to involving themselves in every aspect of business activities to achieve the company's goals becomes important.

The results of this study provide support for institutional theory. The success of an organization in achieving its goals and fulfilling its social responsibilities depends largely on managers. If the manager can do his duties well, the organization will be able to achieve the desired goals and objectives. This is in line with previous research (Ahaotu \& Pathirage, 2015; Machimbi, 2017; Ugboro \& Obeng, 2000). They find that in industries with advanced infrastructure, leadership is a determinant of changes in employee performance. This study's results are different from other studies (Muslikun et al., 2016; Witara, 2017). Leadership does not significantly influence the implementation of quality-based management because, according to him, employees support or are not based more on personal aspects and not because of the direction of the leader. TQM is a strategy chosen and determined by the company. Employees follow this because of aspects of loyalty to the company.

\subsection{Effect of Performance Measurement Systems on Employee Performance}

The analysis showed that the performance measurement system variables did not affect the performance of advanced manufacturing companies in East Java with a significance level of $p=0.001$. Thus the third hypothesis, which states that the performance measurement system influences the performance of employees of advanced manufacturing companies in East Java, is accepted.

Performance measurement systems aim to encourage the achievement of strategic objectives that focus on future organizational activities - benefits of performance measurement for management and employees. Performance measurement provides feedback in the form of strategic control. This control can be used to evaluate and retest how the performance measurement system can increase profitability. This study's results are in line with Nilamsari (2018) and Noronha et al. (2016). This system maintains the focus of individuals in completing their work to contribute strategically to the company. This strategy will generally be in the form of organizational performance. The forms of performance measurement systems such as budget information, budget execution, activity reports, deviation analysis, and corrective actions are not directly related to influencing employee performance. The results of this study are different from the research (Kazan \& Gumus, 2013). They found that the Performance Measurement System did not directly influence employee performance. Measurements made by companies may be only financial measurements. They only comply with statutory regulations. Measuring employee performance must be carried out so that the consumption of human resources becomes more productive.

\subsection{Effect of Performance Measurement Systems on TAM}

The results showed that the management control system affected the implementation of TQM at a significance level of $p=0.011$. The fifth hypothesis, which states the effect of the performance measurement system on employee performance, is accepted. Performance information needs to be reported to line personnel because reporting productivity and quality information to line personnel provides feedback for improvement and learning of production. Performance measurement systems help employees develop strategic work effectiveness. Thus it would be better if performance measurements were linked to quality. Therefore, employees are required to ensure that quality can be continuously improved. This makes the performance measurement system an important factor in the implementation of TAM. 
These results indicate that a fair performance measurement system encourages employees to focus on continuous improvement. Employees are willing to carry out quality improvement activities aimed at providing satisfaction to customers, integrating service processes, making efforts aimed at preventing customer disruption, making efforts aimed at reducing re-service costs, making efforts aimed at reducing complaints from customers, making efforts aimed at reducing customer dissatisfaction, and making efforts aimed at providing a guarantee of service that satisfies customers. The implication is that advanced manufacturing companies in East Java can build a performance measurement system that is fair to employees. The system is driving quality orientation in the operations of advanced manufacturing companies in East Java. Total quality management can be achieved.

This result is in accordance with previous research (Dahal, 2018; Dasrita et al., 2015; Lau \& Oger, 2019). The performance measurement system provides positive motivation for employees always to improve the quality of their performance and as a basis for the follow-up to increase employee competency. In advanced manufacturing companies, a performance measurement system is an integral part of a company's strategic policy. Each employee with the same understanding has understood this system. This makes the values on performance measurements, not a determining factor in changes in employee performance. TQM requires the integration of all elements of the company. All of them require a well-integrated system so that the company's vision, mission, strategy, policies, goals, and objectives can be communicated properly and clearly to all employees. The performance measurement system is part of the company sub-system. A measurement system that satisfies employees stimulates the successful implementation of TQM.

\subsection{Organizational Culture}

The results showed that organizational culture was not proven to affect employee performance at a significance level of $p=0.094$. Organizational culture does not affect changes in employee performance. Values, consensus, habits, and goals that exist in the company affect the way of thinking, communicating, and activities, but do not directly affect employee performance. Employees who follow the organizational culture are directed to follow the norms prevailing in the company. Employees who feel comfortable with the company culture work with please do not necessarily meet the targets expected by the organization.

These results are consistent with previous research. The research found that organizational culture significantly influences performance in an organization (Aletaiby et al., 2017; L.Pathiranage, 2019; Sukdeo et al., 2017; Wisna, 2015). They concluded that culture is a value inherent in organizations. Individuals who are part of the organization directly follow the pattern of behavior that has been built. How well an employee performs the company's organizational culture influences his role in carrying out tasks. A conducive and pleasant organizational culture can be a force capable of directing managers and employees' behavior towards the achievement of organizational goals.

Culture can bridge the resolution of problems that occur within the company. Solving an organizational problem using the values adopted by the company makes employees can accept the solutions taken. Job description clarity with clear procedures also encourages employee congruence with company goals. Job descriptions make employees have clear boundaries about what to do and become their authority. Organizational processes become more efficient and effective. Teamwork is the basis for increasing productivity. If the company employees work together and help each other according to their competency, the work will be easier to complete. The company's overall performance also improved. Such teamwork can help cover the shortcomings of each individual. A culture that builds teamwork has a positive impact on performance improvement. Some studies show different results (F. N. Azizah et al., 2017; Syauta et al., 2012). Employees do not always follow the corporate culture. In this condition, culture is not a factor that determines changes in employee performance. Non-productive cultures certainly do not lead to improved performance.

\subsection{The Effect of Organizational Culture on the Application of TQM}

The results showed that organizational culture was proven to influence employee performance at a significance level of $\mathrm{p}=0.014$. Hypothesis six, which states that organizational culture influences the application of TQM, is accepted. Organizational culture is a determinant of changes in employee performance. Values, consensus, habits, and goals exist in the values, consensus, habits, and goals that exist in organizational culture as a perspective from which to understand the behavior of individuals and groups within the organization. The shared meaning system is organized by employees and management together to form the company's unique characteristics.

If employees view organizational culture as something valuable and willing to work, this behavior supports the company's management. The awareness that the company is jointly owned encourages employees always to make continuous improvements. Companies that provide employees the opportunity to innovate and make decisions for completion of work certainly have a different impact if the company's value adhered to authoritarian. This freedom spurs employees to always think of finding the best way in their duties and work. The stronger the organizational 
culture, the higher the level of employee motivation to work at high-quality standards. The existence of culture drives the behavior of employees who view the survival of the company is important for him. This view affects the way work is done, and the way employees behave.

This result is in line with previous research (Ghani Al-Saffar \& Obeidat, 2020; Sihotang \& Zebedeus, 2013). Advanced manufacturing employees understand that the market wants quality products. The growth mindset is innovation, attention to detail, and outcome orientation, and stability. This organizational culture pattern is aligned with TQM. Therefore, organizational culture is a factor that influences the successful implementation of TQM. This result is different from Gambi et al. (2015). Culture is not a clear predictor of the application of quality management. This culture is characterized by a focus on internal efficiency and predictable outcomes, control, stability, order, and uniformity. All of which are formalized in the form of rules and regulations, and centralized, technically oriented leadership.

\subsection{The Effect of TQM Implementation on Employee Performance}

Based on the results of the regression analysis, it was found that the application of the technique had a significant effect on the performance of employees of advanced manufacturing companies in East Java, as evidenced by the calculation of regression with a significance level of $p=$ 0,000 . Hypothesis seven, which states that the application of TQM techniques affects the performance of advanced manufacturing companies' employees in East Java, is accepted. The better the application of TQM techniques, the higher the performance of employees of advanced manufacturing companies in East Java.

Total Quality Management implemented by advanced manufacturing companies is oriented to the company's internal quality to provide customer satisfaction. TQM is more broadly defined, which covers all aspects of the organization, not only the quality of the product but also the quality of the process, the quality of service, and the quality of the results of other activities in the organization. Managers care about the needs of subordinates. Employee performance is a measure of the quality of employee performance. The company engages managers in developing the company's strategic plan.

The implication is that advanced manufacturing companies can maximize competitiveness and improve management performance through quality-oriented continuous improvement. These improvements include a focus on relationships with suppliers, customer involvement, and training. The purpose of TQM is to provide quality service products that meet the sustainable consumer market's needs and satisfaction (sustainable satisfaction). The success of TQM results in repetitive purchases to increase the productivity of producers reaching economies of scale with the result of reduced production costs.

This study's results are consistent with the research on the application of TQM to significantly influence the performance of employees (Gul et al., 2012; Munizu, 2013; Sukdeo et al., 2017). TQM is a management strategy and philosophy that tries to integrate all organizational functions involving all managers and employees. They are required to cooperate in improving products, services, human resources, processes, and the environment to optimize company performance: the better the TQM, the employee's performance increases. Different studies were conducted (Chaerunisak \& Aji, 2020; Narsa \& Yuniawati, 2003; Ngambi \& Nkemkiafu, 2015). The application of TQM does not necessarily affect performance. The implementation of Total Quality Management has no partial or simultaneous effect on employee performance.

\section{Conclusions}

This study aims to analyze the influence of situational leadership, performance measurement systems, organizational culture, and TQM's application to the performance of employees of advanced manufacturing companies in East Java. From the hypothesis testing, it can be concluded that:

1) The first hypothesis, which states that situational leadership influences the performance of employees of advanced manufacturing companies, is rejected. Situational leadership does not affect the level of employee performance. This indicates that situational leadership is directly unable to change employee performance.

2) The second hypothesis, which states that situational leadership influences the application of TQM, is accepted. Situational leadership influences the success of TQM implementation. The leadership model that considers employee competence is easier to motivate employees to apply high-quality standards and be customer-oriented.

3) The third hypothesis, which states that the performance measurement system influences the performance of employees of advanced manufacturing companies, is rejected. The performance measurement system does not directly affect employee performance. Changes in employee performance levels are not necessarily affected by the performance measurement system.

4) The fourth hypothesis, which states that the performance measurement system influences the application of TQM in advanced manufacturing companies, is accepted. Performance measurement systems directly 
affect employee performance. This indicates that the majority of employees have made efforts to improve quality, integrate service processes, make efforts aimed at reducing re-service costs due to disruption of convenience, in order to satisfy customers.

5) The fifth hypothesis, which states that organizational culture influences the performance of employees of advanced manufacturing companies, is accepted. Organizational culture directly influences employee performance. Changes in employee performance levels are influenced by the comfort felt by employees within the company. This comfort is built on communication patterns, values, norms, and personal relationships. Organizational culture is an aggregation of these elements.

6) The sixth hypothesis, which states that organizational culture influences the application of TQM in advanced manufacturing companies, is accepted. Organizational culture directly influences the application of TQM. This indicates that the majority of employees have made efforts to improve quality, integrate service processes, made efforts aimed at reducing re-service costs due to disruption of convenience, in order to satisfy customers.

7) The seventh hypothesis, which states that the application of TQM affects the performance of employees of advanced manufacturing companies, is accepted. The application of TQM can improve employee performance. This shows that employees have a shared vision and mission, a focus on customers, employee empowerment, continuous improvement, implementing data-based decision-making, and receiving training and development programs. Employee performance improves because assignments are done well.

\section{References}

Ahaotu, S. M., \& Pathirage, C. (2015). Importance of Leadership in Effective Implementation of TQM in the Nigeria Construction Industry. In: 12th International Postgraduate Research Conference (IPGRC 2015).

Aldaweesh, M., Al-Karaghouli, W., \& Gallear, D. (2013). The effective implementation of total quality management and leadership in Saudi Universities: A review and framework to enhancing H.E. strategy. In: European, Mediterranean and Middle Eastern Conference on Information Systems, EMCIS 2013 (pp. 1-13).

Aletaiby, A., Kulatunga, U., \& Pathirage, C. (2017). Key success factors of total quality management and employees performance in Iraqi oil industry. Usir, 668-677. http://usir. salford.ac.uk/43863/

Azizah, F. N., Thoyib, A., \& Irawanto, D. W. (2017). The Influence of Situational Leadership and Organizational Culture on Work Motivation and Employee Performance (Study at Agro-
Commerce Cooperative (KAN) Jabung Malang). Journal of Business and Management, 4(1), 1-11.

Bahbah, A. M. S. (2018). Moderating Effect of Organizational Culture on the Relationship between TQM Implementation and Organizational Performance : Emprical Evedence on Alrahila Oil Services Company - Libya. Saudi Journal of Business and Management Studies, 3(4). https://doi.org/10.21276/ sjbms.2018.3.4.12

Chaerunisak, U., \& Aji, A. (2020). Implementation of Total Quality Management on the Impact of Managerial Performance and Company Profits on MSMEs Yogyakarta. Monetary - Journal of Accounting and Finance, 7, 10-14. https://doi.org/10.31294/ moneter.v7i1.6811

Dahal, R. K. (2018). Management Accounting and Control System. NCC Journal, 3(1), 153-166. https://doi.org/10.3126/nccj. v3i1.20258

Dasrita, T., Rusli Tanjung, A., \& Mutia Basri, Y. (2015). Relationship between Performance Measurement Systems and Managerial Performance: Role of Procedural Justice, Clarity of Roles, and Organizational Commitment as Mediating Variables. Highlight-Journal of Social Sciences, 10(2), 195. https://doi. org/10.31258/sorot.10.2.3215

Dwi Hidayati. (2017). The Influence of Situational Leadership, Performance Measurement Systems, and Application of Total Quality Management Techniques on Management Performance. Developmental Psychology, 16(1), 66-78. https:// doi.org/10.1017/CBO9781107415324.004

Fanani, B., \& Jalil, M. (2016). The Role of Internal Audit on the Quality of Financial Reporting (Survey on Bpr All ExResidency Pekalongan). In: Proceedings of SNaPP2016 Social, Economic, and Humanities (pp. 371-378).

Gambi, L., Boer, H., Gerolamo, M., Jørgensen, F., \& Carpinetti, L. (2015). The relationship between organizational culture and quality techniques, and its impact on operational performance. International Journal of Operations \& Production Management, 35, 1460-1484. https://doi.org/10.1108/IJOPM-12-2013-0563

Ghani Al-Saffar, N. A., \& Obeidat, A. M. (2020). The effect of total quality management practices on employee performance: The moderating role of knowledge sharing. Management Science Letters, 10(1), 77-90. https://doi.org/10.5267/j.msl.2019.8.014

Hamidi, Y. (2009). Strategic leadership for effectiveness of quality managers in medical sciences universities: What skills is necessary. Australian Journal of Basic and Applied Sciences, 3(3), 2563-2569.

Hulima, R. R. (2016). Analyze the Implementation of Organizational Culture To the Employee Performance At PT. Dimembe Nyiur Agripro. Periodic Scientific Journal of Efficiency, 16(3), 290-301

Kazan, H., \& Gumus, S. (2013). Measurement of Employees' Performance: A State Bank Application. International Review of Management and Business Research, 2(2), 429-441.

Koupaei, M. N., \& Movahedi, M. M. (2014). An investigation on the effects of business intelligence and enterprise resources 
planning on TQM. Uncertain Supply Chain Management, 2(3), 191-198. https://doi.org/10.5267/j.uscm.2014.4.001

Kustono, A. S., \& Valencia, Z. G. (2017). How the effectiveness knowledge sharing affect enterprise resource planning system case in East Java-Indonesia. Advanced Science Letters, 23(5), 4295-4297. https://doi.org/10.1166/as1.2017.8263

L.Pathiranage, Y. (2019). Organizational Culture and Business Performance: An Empirical Study. International Journal of Economics and Management Studies, 6(6), 1-12. https://doi. org/10.14445/23939125/ijems-v6i6p101

Lau, C., \& Oger, B. (2019). The Effects Of Comprehensive Performance Measurement Systems On Information Overload, Job-Relevant Information, Role Clarity And Procedural Fairness. In: halshs-02300746, HAL. https://halshs.archivesouvertes.fr/halshs-02300746/document

Lukmana, M. I., Kertahadi, \& Azizah, D. F. (2013). The Influence Of Computer Anxiety and Computer Attitude To The End User Computing Skill (Study on Perum Perhutani Unit II KPH Pasuruan, Malang). Journal of Business Administration, 5(1).

Maulina, E., \& Natakusumah, K. (2020). Determinants of supply chain operational performance. Uncertain Supply Chain Management, $8(1), \quad 117-130 . \quad \mathrm{https}: / /$ doi.org/10.5267/j. uscm.2019.8.001

Mawarni, \& Yuliansyah. (2015). The Effect of Non-Financial Performance Measurement Systems on the Performance of Police Members, Job Tension as a Mediating Factor. Accountability, $\operatorname{VIII(2),~97-110.~}$

Muslikun, Sitawati, R., \& Sutono. (2016). Analysis of the Effect of Total Quality Management (Tqm) on Managerial Performance with Leadership Style, Performance Measurement Systems, and Reward Systems as Moderating Variables. Journal of Management Accounting Economics, 24(40), 1-17.

Mustika, A. (2019). The Effect of Situational Leadership on Employee Performance in PT. Kedaung Tabletop Plaza Pekanbaru. Journal of Economic Appreciation, 7(3), 338-347. https://doi.org/10.31846/jae.v7i3.255

Narsa, I. M., \& Yuniawati, R. D. (2003). The Effect of Interaction Between Total Quality Management and Performance Measurement Systems and Reward Systems on Managerial Performance Empirical Studies at PT. Telkom Divre V Surabaya. Journal of Accounting and Finance, 5(1), 18-34. https://doi.org/10.9744/jak.5.1.pp.18-34

Ngambi, M., \& Nkemkiafu, A. (2015). The Impact of Total Quality Management on Firm's Organizational Performance. MCN. The American Journal of Maternal Child Nursing, 15(4), 69-85.

Nguyen, T., Nguyen, T., \& Pham, T. (2020). The effect of corporate entrepreneurship, organizational culture on supply chain management and business performance in chemical industry. Uncertain Supply Chain Management, 67-76. https://doi. org/10.5267/j.uscm.2019.8.005

Nilamsari, D. P. (2018). Performance Measurement of Professionals in Service Organizations (Case Study of the City of Salatiga). Jemap, 1(1), 129. https://doi.org/10.24167/jemap.v1i1.1588
Ozdal, M. A., \& Oyebamiji, B. F. (2018). Implementation of Total Quality Management and its Effect on Employees'Performance in a Teaching Hospital in Oyo State, Nigeria. 1-8. https://doi. org/10.23880/phoa-16000129

Rad, A. M. M. (2006). The impact of organizational culture on the successful implementation of total quality management. TQM Magazine, 18(6), 606-625. https://doi. org/10.1108/09544780610707101

Rahman, M. M., \& Saima, F. N. (2018). Efficiency of Board Composition on Firm Performance: Empirical Evidence from Listed Manufacturing Firms of Bangladesh. Journal of Asian Finance, Economics and Business, 5(2), 53-61. https://doi. org/10.13106/jafeb.2018.vol5.no2.53

Rotberg, B. (2016). Culture and IFRS: The effect of Culture on IFRS Implementation and financial Reporting Quality. Radboud University. http://theses.ubn.ru.nl/handle/123456789/3572

Saad, G. B., \& Abbas, M. (2018). The impact of organizational culture on job performance: A study of Saudi Arabian public sector work culture. Problems and Perspectives in Management, 16(3), 207-218. https://doi.org/10.21511/ppm.16(3).2018.17

Saleh Al-Dhaafri, H., Zien Bin Yusoff, R., \& Kaid Al-Swidi, A. (2014). The relationship between enterprise resource planning, total quality management, organizational excellence, and organizational performance-the mediating role of total quality management and organizational excellence. Asian Social Science, 10(14), 158-178. https://doi.org/10.5539/ass.v10n14p158

Salehipour, A., \& Ahmand, A. (2018). The Impact of Organizational Culture and Performance Work System on Employees' Performance. International Business Research, 11(6), 199. https://doi.org/10.5539/ibr.v11n6p199

Seyedi, H., Mohebbifar, R., \& Rafiei, S. (2019). Quality Management System and its Role in the Quality Maturity of Training Hospitals. Journal of Client-Centered Nursing Care, 5(2), 113-122. https://doi.org/10.32598/jccnc.5.2.113

Sihotang, R. B., \& Zebedeus, Z. V. (2013). Relationships between Total Quality Management Practices, Organizational Culture and Teacher's Performance: Study from Seventh Day Adventist High Schools in West Indonesia. International Research Journal of Business Studies, 6(2), 105-119. https://doi.org/10.21632/ irjbs.6.2.105-119

Striteska, A. M., \& Jelinkova, B. L. (2015). The Characteristics of Effective Performance Measurement System: Case Study Analysis. Recent Advances in Environmetal and Earth Science and Economics, 290-295. http://www.inase.org/library/2015/ zakynthos/bypaper/ENG/ENG-47.pdf

Sukdeo, N., Pretorius, J. H., \& Vermeulen, A. (2017). The role of Total Quality Management (TQM) practices on improving organisational performance in manufacturing and service organisations. In: Proceedings of the International Conference on Industrial Engineering and Operations Management, 2017(OCT), 1133-1152.

Syauta, J. H., Troena, E. A., Setiawan, M., \& Solimun. (2012). The Influence of Organizational Culture, Organizational 
Commitment to Job Satisfaction and Employee Performance (Study at Municipal Waterworks of Jayapura, Papua Indonesia). International Journal of Business and Management Invention, 1(1), 2319-8028.

Talib, F., Rahman, Z., \& Qureshi, M. N. (2011). Prioritising the Practices of Total Quality Management: An Analytic Hierarchy Process Analysis for the Service Industries. Total Quality Management and Business Excellence, 22(12), 1331-1351. https://doi.org/10.1080/14783363.2011 .625192

Trang, T. V., \& Do, Q. H. (2020). Critical Success Factors of TQM Implementation in Vietnamese Supporting Industries. Journal of Asian Finance, Economics and Business 7(7), 391-401. https://doi.org/10.13106/jafeb.2020.vol7.no7.391

Ugboro, I. O., \& Obeng, K. (2000). Top management leadership, employee empowerment, job satisfaction, and customer satisfaction in TQM organizations: an empirical study. Journal of Quality Management, 5(2), 247-272. https://doi.org/10.1016/ s1084-8568(01)00023-2

Ul-Hameed, W., Mohammad, H. B., Shahar, H. B. K., Aljumah, A. I., \& Azizan, S. B. (2019). The effect of integration between audit and leadership on supply chain performance: evidence from UK based supply chain companies. Uncertain Supply
Chain Management, 7(2), 311-328. https://doi.org/10.5267/j. uscm.2018.8.001

Wambugu, L. W. (2014). Effects of Organizational Culture on Employee Performance (Case Study of Wartsila -Kipevu Ii Power Plant). European Journal of Business and Management, 6(32), 80-93.

Wanjiku, N. A., \& Lumwagi, N. (2014). Effect of Organisation Culture on Employee Performance in Non Govermental Organizations. International Journal of Scientific and Research Publications, 4(1), 2250-3153.

Wei, F., \& Xiong, Z. (2020). Review of Sustainable Supply Chain Performance Evaluation. In: Proceedings of the 5th International Conference on Financial Innovation and Economic Development (ICFIED 2020) (pp. 194-198). https:// doi.org/10.2991/aebmr.k.200306.034

Yuliana, M. (2013). The Influence of Reliatation Safety and Healthy Work to Work Productivity Employees at PT PLN (Persero) Jawa Barat and Banten. International Journal of Science and Research, 2(1), 701-707.

Zulaihah, I. (2017). Contingency Leadership Theory / Situational Approach. Al-Tanzim: Journal of Islamic Education Management, 1(1), 76-87. https://doi.org/10.33650/al-tanzim.v1i1.29 